International Journal of Applied Linguistics \& English Literature

ISSN 2200-3592 (Print), ISSN 2200-3452 (Online)

Vol. 1 No. 3; July 2012 [Special Issue on World Literature in English]

\title{
Reading Glimpses of Life and Manners: A Textual Practice
}

\author{
Farah Ghaderi \\ Urmia University, Iran \\ Wan Roselezam Wan Yahya \\ Universiti Putra Malaysia, Malaysia
}

Received: 10-07- 2012

Accepted: 25-07- 2012

Published: 31-07- 2012

doi:10.7575/ijalel.v.1n.3p.76

URL: http://dx.doi.org/10.7575/ijalel.v.1n.3p.76

\begin{abstract}
Through a textual scrutiny of Mary Sheil's Glimpses of Life and Manners in Persia, this paper aims to examine the ways she represents the Persian women in her travel narrative. Nineteenth century, as the high noon of British imperialism, saw the emergence of a huge corpus of colonial travel literature on Persia purported to be eye-witness accounts of the journeys made by their writers. Likewise, Mary Sheil claims that her narrative is an innocent transcription of the life and manners in Persia. However, a close analysis of her text reveals that the representations of women are informed by circulating discourses of the time in keeping with British imperialist ideologies. Further, it exposes the power structure embedded in Sheil's scripting of Persian women. Far from being a monolithic picture, the text presents an ambivalent tableau of Persian women as objects of both derision and admiration. For its analytical framework, this study follows three successive readings focusing on the representation of the Persian women. The interpretation of the passages is guided by theories from Edward Said and Homi K. Bhabha among others.
\end{abstract}

Keywords: Nineteenth-century travel writing; colonial discourse; Persian women; ambivalence; representation

\section{Introduction}

There is a mammoth body of travel writings authored by Western male and female writers on the colonial worlds. ${ }^{1}$ The prejudiced assumptions about the colonial peoples and their manners and mores reflected in the travel texts were regarded as authentic information. This huge corpus of travel writing not only entertained the home audience but also justified imperial expansionistic projects. It was in the last three decades of the twentieth century that publications such as Edward Said's Orientalism (1978) aroused doubts as to the objectivity and reliability of the images of the non-European echoed in the colonial archive, i.e. western textual creation of the rest of the world. Accordingly, travel writings on colonial world have been attracting an increasing amount of critical attention. Postcolonial travel theorists have repeatedly affirmed the centrality of travel literature in the perpetuation and advancement of imperial objectives. The ample textual analyses, carried out on the travel narratives on nonEuropean countries such as Egypt, China, and India, among others, revealed the submerged imperialist ideologies, assumptions, and dogmas in the construction and representation of the colonized milieu. To cite examples, Mary Louise Pratt (1992) argues that the considerable body of travel writing by male and female colonial writers was meant to, "reaffirm metropolitan authority in its own terms- the very thing travels are often charged to do" (5). Also, Duncan and Gregory (1999) contend that "there is a sense in which all travel writings, as a process of inscription and appropriation, spins webs of colonizing power"(3). And very recently, in introduction to their compilation Travel writing, Form, and Empire, Kuehn and Smethurst maintain "the construction of binaries in the context of imperialist travel writing might be considered a discursive and rhetorical strategy consistent with imperialist ideology" (2009: 9). Although imperialist travel writings on the colonized countries have been the subject of numerous studies, the huge body of Victorian travel literature on semi-colonized Persia particularly British women's travel writing has been left as a relatively unexplored area.

\section{Discussion}

There is a huge body of European travel writing, mostly British, on Persia during the nineteenth century as the heyday of British imperialism. Due to its strategic position, placed between the southern borders of Russia and westernmost borders of British India, Persia became an open scene of rivalry known as the 'Great Game' between those two imperial powers. This situation brought about a new type of British informal colonial dominance in Persia (Andreeva, 2007: 5-6). To achieve its imperial objectives in the far-off land of Persia, Britain's indirect 
International Journal of Applied Linguistics \& English Literature

ISSN 2200-3592 (Print), ISSN 2200-3452 (Online)

Vol. 1 No. 3; July 2012 [Special Issue on World Literature in English]

sphere of influence had to be legitimized repeatedly by presenting Persians as inferior Other in need of British civilizing and chivalric mission. Nineteenth century British travel writing on Persia has partly contributed to the aforementioned end by perpetuating the representations of Persia in keeping with imperialistic ideologies.

Mary Sheil's travel account is the first recorded woman's travel writing on Persia. From the very opening of her narrative, she authorizes her representations of the Persian milieu by claiming that they are based on eyewitness accounts and first-hand knowledge. This paper aims to present a postcolonial study of her narrative, entitled: Glimpses of Life and Manners in Persia: With Notes on Russia, Koords, Toorkomans, Nestorians, Khiva, and Persia (1856) (henceforth Glimpses of Life and Manners).

Methodologically, we will conduct three successive readings to interpret the text under study. The first simple reading aims to provide a synopsis. The second reading focuses on extracts of the text that deal with the representation of Persian women. We shall interpret the chosen extracts, using Edward Said's view of Orientalist representations of the Orient in Orientalism (1978) as a critical tool. In the third reading, we shall scrutinize those extracts on women representations that cannot be explained in the light of Said's theory. In this final reading, Homi $\mathrm{K}$. Bhabha's theory of ambivalence in the colonial discourse is drawn upon to delineate the ambivalent nature of women representations. We shall then draw our conclusions from the result of these three readings.

\section{First Reading: Synopsis}

Glimpses of Life and Manners is Mary Sheil's account of a nearly three-and-half-year journey and residence in Persia, supplemented by Notes authored by her husband, Sir Justin Sheil - the British minister referred to in the text as Colonel S-. On the 7th of August, 1849, the Sheils embarked on the journey through Poland and Russia. After about three months they arrived in Persia on October 29th. Their travel included cities as Tabriz, Kasveen, Tehran, Mazenderan, and Ispahan. In February 1853, due to Colonel's bad health, they decided to leave the Persian land. The account of their journey and residence in Persia was published three years later in 1865. Employing an itinerary form presented in 29 chapters, Mary Sheil provides the reader with a host of information about Persia. Despite her humble choice of the term 'glimpses' in the title, her narrative covers in great details almost every single aspect of Persian milieu, and includes descriptions of landscapes, cities, gardens, religious ceremonies, trade, the Shah's mother and wives, and the interiors of harems. Apart from Mary Sheil's own accounts, almost one third of the book is devoted to Colonel S-'s Notes to cover "many subjects not accessible to female inquiry" in that "portion of the East" (Sheil, 1856: 1). The Notes provide the readers with detailed and sometimes tabled information on the Persian army, revenue, silk manufacture, ethnographic portrayal of tribes as well as men's drinking parties.

\section{Second Reading: Applying Said's View of Orientalist Discourse}

The second reading traces women representations in the narrative and interpret them in the light of Said's theory about Orientalist construction of the Other. We have decided to focus on women representations since to me, of all the images of Persia, none is as central and telling as the question of women construction given their crucial status in epitomizing a nation and its culture. Employing Orientalist discourse for the interpretation of the data best suits this study of Mary Sheil's narrative given the political status of Persia during the time it was written which has undeniably affected her representation of the country.

Orientalist discourse is a system of ideological construction which has its roots in imperialistic ideologies exposed by Said in Orientalism. Said (1979) argues that the Orient depicted in the colonizer's literature is not an authentic representation; rather, it is through the power of Orientalist discourse that such depictions are made possible and plausible. Representation is embedded at the core of Orientalist discourse and it involves questions of subjectification and domination. For the purpose of this paper, WE shall confine the discussion to passages where women are dehumanized, eroticized, and portrayed as objects of theatrical entertainment. Italics are used in the quoted passages to highlight the key phrases and sentences being discussed.

\section{Dehumanized Representation}

Dehumanization, as an influential strategy for relegating the Orient to the state of the Other in the Orientalist discourse informs Sheil's narrative. The following excerpt is an illustrative example of how Sheil dehumanizes the Persian town women:

If they [town women] are young, handsome, or powerfully connected, matters are tolerably smooth. But when the wife loses her personal attraction she often sinks down to a household 
International Journal of Applied Linguistics \& English Literature

ISSN 2200-3592 (Print), ISSN 2200-3452 (Online)

Vol. 1 No. 3; July 2012 [Special Issue on World Literature in English]

drudge; and at the best is seldom free from contention with her rivals in the haram. I do not think a Persian woman ever feels the same affection for her husband as some Europeans do. Persian women seem to me to have no idea of a calm, tranquil life. Novelty, or whatever excitement, is what they seek, and, I dare say, they would be miserable without that stimulus. They have not strong religious or moral principle; and the example of their husband is said to be no encouragement to domestic happiness. $\quad(1856: 144)$

The adopted Orientalist gaze passes judgment on the Persian women by homogenizing them into 'they/she' and fixing them in the unchangeable present time used for her ethnographic depiction in the above passage. Persian women are harshly dehumanized by being represented as stripped of their conjugal "affection" and "religious and moral principles". There is also an implicit criticism of Persian men as being superficial in the second line of the quoted passage where their love is reduced to the looks. Women are also depicted to be competitive with one another and having no sense of sisterhood. Moreover, they are represented as superficial and childish seeking "excitement" as the only "stimulus" to fill their empty life. The dehumanizing side of discursive representations is accentuated by Said stating that Orientalist discourse is "disregarding, essentialising, denuding the humanity of another culture, people or geographical region" (1979: 108). This in turn could justify the need for British intervention in Persia presented as a civilizing and chivalric mission on behalf of the oppressed, ignorant and uneducated Persian women.

\section{Erotic Representation}

The other dominant image of women in the text represents them as erotic objects. Adopting a male voyeuristic gaze, Sheil's meticulous verbal portrait of the Shah's mother objectifies and eroticizes her as nude, bejeweled and painted in the following passage.

Her [the Shah's mother] trousers were edged with a border of Pearls embroidered on braid; she had a thin blue crepe chemisette, also trimmed with pearls; this chemisette hung down a little below the waist, nearly meeting the top of the trousers, which are fastened by a running string. As there was nothing under the thin gauze, the result of course was more display than is usual in Europe. ...her arms were covered with handsome bracelets, and her neck with a variety of costly necklaces. Her hair was in bands, and hung down under the shawl, in a multitude of small plaits. She were no shoes, her feet being covered with fine Cashmere stockings. The palms of her hands and tips of her fingers were dyed red, with a herb called henna, and the edges of the inner part of the eyelids were coloured with antimony. All Kajars have naturally large arched eyebrows...her cheeks were well rouged, as is the invariable custom among Persian women of all classes. (1856: 132-33)

The reference to the images of "nearly meeting the top of trousers", "nothing under the thin gauze", and "more display than is usual in Europe" in the above depiction is suggestive of bare skin being exposed, thus lack of modesty. Such a description of the Shah's mother to the British readers of Victorian era who had to follow strict dress codes even for their pets can be very effective in presenting a Persian woman as an erotic object. Moreover, Sheil's accent on the exaggerated use of make-up and extravagant wearing of jewellery italicized in the above passage enhances the erotic implications of this description since it would convey the image of "the prostitute or, her equivalent, the actress" to the Victorian audience (Melman, 1995: 116). The painted face is generalized in Sheil's choice of terms such as "All the Kajars" and "Persian women of all classes" and it is fixated in her usage of present tense and the adjective "invariable". Given the Victorian connotation of the image and its generalization and essentialisation by Sheil, Persian women of all classes are eroticized and objectified. Considering the patriarchal nature of colonization, this erotic tableau of the country can be very alluring in attracting the male dominance of the land.

\section{Theatrical Representation}

The representation of the Persian women as the objects of theatrical entertainment and the accompanying implicit imperialistic objective is most clear in the following passage in which Sheil describes a religious ceremony:

I was conducted to a very comfortable loge, with an antechamber, or kefshken, "slipper-casting" room, where one leaves the outer shoes. The front of the box carefully covered over with a thick felt carpet, pierced with small holes, which, while they allowed us to 
International Journal of Applied Linguistics \& English Literature

ISSN 2200-3592 (Print), ISSN 2200-3452 (Online)

Vol. 1 No. 3; July 2012 [Special Issue on World Literature in English]

see all that passed, and completely excluded us from the view of the audience. Part of the pit was appropriated to women of humble condition, who were in great numbers, all however carefully veiled, and all seated on the bare ground. Before the "curtain drew up," it was ludicrous to witness the contention among these dames for places, which was not always limited to cries and execrations. They often proceeded to blows, striking each other heartily on the head with the iron heel of their slippers, dexterously snatched off the foot for the purpose; and, worse still, tearing off each other's veils; several ferashes[male guard] were present to keep the peace, armed with long sticks, with which they unmercifully belaboured these pugnacious devotees. (1856: 127-28)

The distance between Sheil, as the wife of British minister lodged in a superior comfortable position, and Persian women struggling for room on the "bare ground" is accentuated from the very opening of the passage. This distance is more secured since she is the only one with the power of objectifying gaze given that there is no possibility for her gaze to be returned; she is well excluded "from the view of the audience". In her panoramic position, Sheil maps out a comic scenario of fighting between "women of humble condition" through narrating an eye witness account of acting out of the slaughter of Imām Hoossein, prophet Mohammad's grandson, and his family at Kerbella. The conversion of a religious solemn ceremony to a comic theatre seems to be a projection of her imagination to compensate for her disappointment with the public nature of the performance which has destroyed the sense of mystery of the East that she would rather preserve. Sheil describes the stage as "perfectly open on every side, and revealing, to the entire destruction of all exercise of the imagination, the mysteries which ought to pass behind the curtain" prior to the above passage (1856: 127). Moreover, it serves to devalue this Islamic religious ceremony. This Orientalist construction is employed both to entertain her home readers and to present Persian women as violent and savage in need of civilizing mission. The cruel picture of guards with their "long sticks" necessitates the pressing need for a paternal protection to save Persian women from Persian men.

Employing tropes in the Orientalist discourse, Sheil has objectified Persian women in her representation and reduced them to the status of Other as dehumanized, erotica and savage. This, in turn, secures the superior position of the British women in the fixed dichotomy of self/other as argued by Said in Orientalism. Furthermore, placed against the Victorian 'angel-in-the-house', as the embodiment of modesty and self-sacrifice for the betterment of her family, the homogenized and essentialized representations of Persian women in the discussed passages seem more lacking in true womanliness. This justifies the need for British civilizing and chivalric roles to act on behalf of Persian women, which further promotes British presence in the country.

\section{Third Reading: Applying Bhabha's Theory of Ambivalence}

Though the greater part of Sheil's narrative concentrates on denigrating the Persian women, there are instances where they are depicted as subjects of manifest admiration. Besides, there are contradictory representations of the same characters within the text. Said's theory of Orientalism emphasizes the fixed nature of stereotypes to perpetuate the binaries of civilized/barbarous and superior/inferior needed to justify the colonial domination. Since this theory emphasizes the monolithic representation of the colonized, it fails in explaining the few vacillating and inconsistent depictions of Persian women in Sheil's narrative. Accordingly, there arises the need for an additional theoretical tool to account for the discrepancies in women representation in the narrative under study.

The postcolonial theorist Homi K. Bhabha has brought to light the ambivalent nature of the stereotypes in colonial discourse of the Other. Bhabha (1994) maintains that the stereotype is a complex and ambivalent mode of representation of Otherness, which functions as a significant discursive strategy of colonial discriminatory power; it is "the force of this ambivalence that gives the colonial stereotype its currency," upon which colonial discourse is highly dependent (66). He argues that the ambivalent nature of colonial stereotypical discourse simultaneously enables and undermines the fixity needed to sustain colonial dominance. And it is this "productive ambivalence" which allows for a wide range of stereotypical depictions through which the colonial relationship is facilitated (67; italics original). Bhabha's theory of ambivalence in Orientalist discourse allowing for vacillating, slippery and contradictory stereotypical representations will be drawn upon as my main theoretical aid in explaining the following inconsistencies in Sheil's depiction of Persian women.

Describing Tehrani women's visit to the physician, Sheil hints at the possibility of erasing the difference between the Persians and the Europeans under colonial dominance. Her description is worth quoting at length for its colonial implications. 
International Journal of Applied Linguistics \& English Literature

ISSN 2200-3592 (Print), ISSN 2200-3452 (Online)

Vol. 1 No. 3; July 2012 [Special Issue on World Literature in English]

The dreadful practice of the Persian doctors is quite enough to drive the fair dames of Tehran to an English physician. ... [T] hey divide all maladies into cold and hot, which are to be attacked by corresponding opposite medicines. Thus a hot disease is to be combated by a cold remedy. The classifications of these last are somewhat fanciful. ... The anderoon[harem] seems open to him [the English physician]. Husbands and brothers, in company with their wives and sisters, used to sit in their anderoon with our "hakeem sahib," gossiping and chatting as gaily and freely as they would do in Europe. It is a pity that these cheerful Iranees are so far off; they would otherwise soon become Feringhees[Europeanized]. With all their alacrity to endure a life of roughness, or even hardship, they have a vast aptitude for luxury and enjoyment; which may be regarded as the high road to civilization. Their wants are increasing daily, and these wants must be supplied from Europe. (Sheil, 1856: 213-14)

Sheil relegates the practice of the Persian doctors to 'fancy', which is dreadful enough to make beautiful Tehrani girls go to English doctor whose practice is based on modern science. The representation of these fair dames as enjoying their lives like Europeans could be best explained through Bhabha's theory of ambivalent stereotypical discourse. According to Bhabha (1994), the representation of the difference between the natives and colonizers in colonial literature is ambivalent. On the one hand, like the above instance, the difference is domesticated, which means that "under certain conditions of colonial domination and control the native is progressively reformable" (83).The italicized parts of the extract depicts the "cheerful Iranees" of the capital as ready and willing to embrace the scientific European practices and to become Europeanized, or so to speak, civilized. Their vast potential for a civilized life is only realizable via a direct colonial presence, through which the problem of distance is solved and their daily increasing wants are quickly met. The closing sentence of the quoted passage demonstrates Sheil's awareness of the economic importance of British colonialism

On the other hand, Bhabha contend the difference between the two is made "more visible" to deny the natives "the capacities of self-government" (1994: 83). Bhabha's point is exemplified in the following extract which depicts Sheil's 'brave' visit to "Looristan, the abode of a genuine Persian race, the worst and most ferocious robbers throughout the land" (1856: 223).

\begin{abstract}
Europeans have been, no doubt, deterred from penetrating the almost inaccessible haunts of these lawless mountaineers, either by the danger, or by the want of objects of curiosity to compensate for the risk. Yet there is an attraction in examining a state of society so unlike our own, where there is little or no law, and where personal freedom is carried to the verge of dissolving the bonds of society. ... A nearer examination generally dispels the visions one may have formed of these supposed unsophisticated beings, passing their lives in the solitude of their mountains, engaged in the care of their flocks and herds. The unveiled display of intense avarice, of poverty, squalor, ferocity, idleness, and tyranny among the men, toil and slavery among the women, soon displays the naked reality, and disgust succeeds sympathy. (Sheil, 1856: 224-25)
\end{abstract}

Unlike the Tehrani women, in the previous extract, who are represented as enjoying the privileges of Europeanlike treatment by their brothers and husbands, Looristani women are depicted as being doomed to a life of "toil and slavery". Sheil's scrutiny reveals the "naked reality" of the life and manners of the natives of Looristan. The last sentence of the above passage demonstrates how markedly different they are from the British. So, there arises a call for "authoritarian forms of political control". "The necessity of such rule," as Bhabha might argue "is justified by those moralistic and normative ideologies of amelioration recognized as the Civilizing Mission or the White Man's Burden" (83).

Bhabha's theory of the slippery nature of the ambivalent stereotypical discourse accounts for the contradictory and multiple representations of Sheil's servants within her narrative. Bhabha believes that the productive ambivalence of the colonial stereotypical discourse allows for "the wide range of the stereotype, from the royal servant to Satan, from the loved to the hated; a shifting of subject positions in the circulation of colonial power" (1994: 79). In the following excerpts, her servants are represented in ambivalent terms, as inspiring both repulsion and attraction:

I have had a good deal of experience of Persian nurses. ...When they are in a passion they tear their hair and scratch their bosom with their nails until the blood comes. ... These women were 
International Journal of Applied Linguistics \& English Literature

ISSN 2200-3592 (Print), ISSN 2200-3452 (Online)

Vol. 1 No. 3; July 2012 [Special Issue on World Literature in English]

very exact in their devotions; at daybreak they would rise, perform the prescribed ablutions, and unwrapping a stone that had been brought from Kerbella, placing it carefully towards Mecca, they went through the usual form of prostration and prayer; this they repeated three times every day. (Sheil, 1856: 239)

Persian nurses are represented as both barbarous and religiously devoted. Implied in this passage also is that Islamic observances are superficial performed merely by the habit without effecting a change in the devotee. Moreover, there is Western representation of Islam as a religion of violence which does not keep its devotees from barbarous behaviour. Sheil's ambivalent is also evident in her depiction of her servants: "Persian servants in a house are absolutely worthless, they do nothing; but on a journey they are admirable, full of activity and attention, and they seem never to suffer from fatigue" (1856: 260).

According to Bhabha (1994), ambivalence allows for a wavering attitude toward the natives, sometimes derisive, sometimes admiring (67). Even though in an earlier depiction (discussed under dehumanization of women in the second reading of the present essay), she dismisses all Persian women as lacking in their feelings for their husbands, there are a few instances where Sheil expresses admiration for women's conjugal feelings.

In the following example Sheil tells the story of an "exemplary Lady" who is the Shah's sister and the wife of the Prime Minister, Meerza Tekkee Khan. He was a capable minister under whom Persian army and finance were flourishing. His popularity among people made his jealous enemies at the court to persuade the King to overthrow him. After his downfall, he was to be put under the protection of the British minister and "arrangements were made for his maintenance in honour and luxury in a neighbouring city, and of course in safety" (Sheil, 1856: 250). According to Sheil's narrative, his false move at the very last moment by casting off the British protection brought about his imprisonment in Cashan with his wife and his subsequent murder. Furthermore, his poor widowed wife had to undergo an enforced marriage at the King's order to the son of the new Prime Minister. Imagining herself in a chivalric role, Sheil, who 'happens' to approach the couple on their way to Cashan, describes them in a sympathetic tone:

\begin{abstract}
His wife, the Shah's sister, a young woman of eighteen, resolved to accompany her husband, in spite of the dissuasions of her brother and her mother. Conjugal affection does exist in Persia after all. A few days afterwards, as we were driving outside the walls of the town, I unexpectedly approached within a few yards of a party travelling towards Ispahan. It was the Ameer and the princess. They were both in a takhterewan, surrounded by guards. It seemed to me like a funeral procession, and I have seldom beheld a more melancholy sight. I longed to open the carefully closed takhterewan; to take the doomed Ameer and his poor young wife with their two infant children into the carriage, and to drive off with them to the Mission-house.

(1856: 250-51)
\end{abstract}

The genuine and deep love of the princess for her husband is highlighted by her sacrificial decision to taste all the food presented to her husband during the several months of their confinement in Cashan: "As a security against poison, that exemplary lady made it a rule to partake first of all the food presented to the Ameer" (Sheil, 1856: 251). This seemingly innocent story of the doomed couple implicitly complies with the colonial imperatives in two ways. First, the worthy minister who is working for the welfare of the people is not treasured by the corrupt Persian court, implying that there is a pressing need for a just colonial rule. Second, the emphasis on the princess's conjugal affection reinforces the bitterness of their unjust treatment by the King and the harsh outcome of casting off the British protection. Sheil remarks this tragic end could be avoided by a wise decision on the part of the Prime Minister to let her family enjoy a perfect life under the British protection, which by extension means such a life for the whole country.

\title{
Conclusion
}

Employing a textual scrutiny of three successive readings, the paper has been an attempt to dismantle the colonial imperatives embedded in the professedly 'innocent' travel narrative of Sheil, focusing on the representations of women. The first reading provided a synopsis of Sheil's travels to and in Persia. In the second reading, passages on women representation were interpreted in the light of Said's theory of Orientalist representation of the Orient. This reading showed that women are constructed through the colonial gaze as inferior other in need of civilizing improvement, thereby legitimizing British informal dominance in the country. The aim of the third reading was to 
International Journal of Applied Linguistics \& English Literature

ISSN 2200-3592 (Print), ISSN 2200-3452 (Online)

Vol. 1 No. 3; July 2012 [Special Issue on World Literature in English]

examine passages where the portrayal of women cannot be explained in terms of Said's notion of Orientalist discourse because the representations are not always fixed and straightforward, but ambivalent. Bhabha's theory of the ambivalent stereotypical discourse was then used to interpret these passages, to argue that the slippery and ambivalent nature of these portrayals permits the representation of Persian women as reformable but oppressed in Persia, and therefore in need of emancipation under colonial guidance. In these respects, it may be argued that Glimpses of Life and Manners comply with the considerable body of narratives on Persia by travellers during the nineteenth century, which depict Persians in need of civilizing mission in order to justify the informal imposition of British influence in Persia.

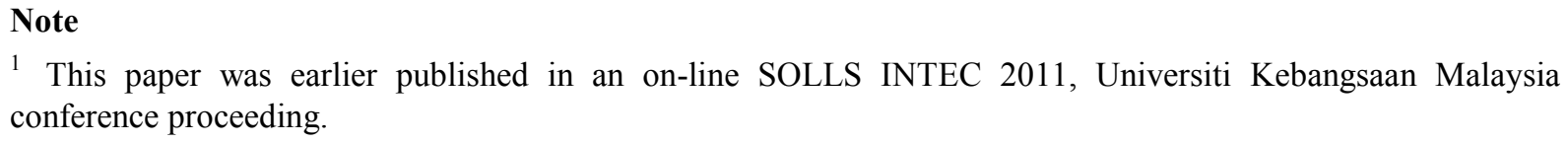

1 This paper was earlier published in an on-line SOLLS INTEC 2011, Universiti Kebangsaan Malaysia conference proceeding.

\section{References}

Andreeva, Elena. (2007). Russia and Iran in the Great Game. London and New York: Routledge.

Bhabha, Homi K. (1994). The Location of Culture. London and New York: Routledge.

Curzon, George N. (1966). Persia and the Persian Question. 2 vols. London: Frank Cass \& Co. Ltd.

Duncan, James \& Derek Gregory, eds. (1999). Writes of Passage: Reading Travel Writing. London: Routledge.

Kuehn, Julia \& Paul Smethurst, eds. (2009). Travel Writing, Form, and Empire: The Poetics and Politics of Mobility. London and New York: Routledge.

Melman, Billie. (1995). Women's Orient: English Women and the Middle East, 1718-1918: Sexuality, Religion and Work. 2nd ed. London: Macmillan.

Pratt, Mary Louise. (1992). Imperial Eyes: Travel Writing and Transculturation. New York: Routledge.

Said, E. W. (1979). Orientalism. New York: Vintage Books.

Sheil, Mary Leonora Woulfe. (1856). Glimpses of Life and Manners in Persia. London: John Murray.

\section{Farah Ghaderi}

Farah Ghaderi is a lecturer in the Department of English, Urmia University, Iran. She is currently pursuing her postgraduate studies in English Literature at the Faculty of Modern Languages and Communication, Universiti Putra Malaysia.

\section{Wan Roselezam Wan Yahya}

Wan Roselezam is Associate Professor of English Literature at the Faculty of Modern Languages and Communication, Universiti Putra Malaysia. She is involved in several researches dealing with literature \& culture, psychoanalysis \& literature, literature in ESL, and diasporic literature. 